\title{
The Role of Parenting Style to the Feeling of Adequately Heard and Subjective Well-Being in Perpetrators and Bullying Victims
}

\author{
Ihsana Sabriani Borualogo ${ }^{1}$ \\ Faculty of Psychology, Universitas Islam Bandung
}

Submitted 3 December 2020 Accepted 22 February 2021 Published 23 April 2021

\begin{abstract}
This study aimed to explain the contribution of parenting styles on children's perception of being adequately heard by parents and their subjective well-being across three bullying groups (perpetrators, victims, and uninvolved). Participants ( $\mathrm{N}=1,294$; $54.8 \%$ girls; $45.2 \%$ boys) were elementary school $(47.3 \%)$ and junior high school students (52.7\%) in Bandung City. Parenting styles were measured using Egna Minnen Beträffande Uppfostran for Children. Subjective well-being was measured using the Children's Worlds Subjective Well-Being Scale. Being adequately heard by parents was measured using the Children's Worlds measure. Data were analysed using linear regression and descriptive analysis. Parenting styles contributed significantly to children's perception of being heard by parents and their subjective well-being. Parenting styles contributed differently across the three groups and genders. The uninvolved perceived that their parents were warm. The perpetrators perceived their parents as rejective. The victims perceived their parents as overprotective. The perpetrators displayed the lowest SWB score, while the uninvolved displayed the highest SWB score. Warm mothers showed a significant positive effect on children's SWB and perception that they were adequately heard. Overprotective fathers showed a significant positive effect on children's SWB because father was perceived as the family's head who protects their children. It is suggested that parents should practice warm rearing to prevent children's involvement in bullying.
\end{abstract}

Keywords: being adequately heard by parents; bullying; parenting styles; subjective well-being

Indonesia's National Child Protection Commission reported the high rate of bullying incidents in Indonesia that increased over the years. Bullying is aggressive behaviour that is done intentionally to hurt others repeatedly because of the imbalance of power and strength between the perpetrator and the victim (Espelage \& Swearer, 2003; Olweus, 1997). There are three indicators of bullying, which are physical (e.g., hitting, kicking), verbal (e.g., name-calling, threatening), and psychological (e.g., left out, social exclusion) (Borualogo \& Casas, 2019b; Espelage \& Hong, 2019). Bullying can happen anywhere, but 
one of the bullying types with a high frequency of incidents is school bullying (Borualogo \& Gumilang, 2019). Students can be a perpetrator or a victim.

From 2011 until 2019, Indonesia's National Child Protection Commission received 2,473 school bullying reports (kpai.go.id). These cases are trending to increase over the years. The Global School-Based Health Survey (GSHS) report in 2015 showed that 32\% of students aged 13-17-year-olds in Indonesia were physical violence victims, and 20\% were school bullying victims (Kementerian Perencanaan Pembangunan Nasional and Unicef, 2017). These percentages were the highest in Asia. The Programme for International Student Assessment (PISA) showed that $41 \%$ of Indonesian students were bullying victims (Schleicher, 2018). Trends in Mathematics and Science Study report (Mullis et al., 2016) also showed inline results where $56 \%$ of students age $11-15$-year-olds were school bullying victims. The Children's Worlds report showed that $27.1 \%$ of students were hit by other students at school, $36.7 \%$ of students were name-called by other students at school, and $26.5 \%$ of students were left out by other students in the class (Borualogo \& Gumilang, 2019). Bullying incidents most frequently happen in elementary and middle school (Borualogo et al., 2020b; Fitzpatrick \& Bussey, 2011). Therefore, the focus of this study was school bullying in elementary and middle school students.

Several studies showed that bullying harms children's mental health. Bullying decreases children's life satisfaction (Varela et al., 2019), dan has a negative effect on the children's subjective well-being (SWB) (Borualogo \& Casas, 2019b; Savahl et al., 2019; Tiliouine, 2015).

Studies on the contribution of bullying to SWB mostly focused on bullying victims (Alcantara et al., 2017; Borualogo \& Casas, 2019b; Savahl et al., 2019; Tiliouine, 2015). A study done by Savahl et al. (2019) in 15 countries showed that the SWB of bullied children were significantly lower than children who were not bullied. A study in Indonesia (Borualogo \& Casas, 2019b) also showed inline results where Indonesian children who were school bullying victims significantly showed lower SWB than children who were not involved in bullying. Another study showed that the SWB of children involved as perpetrator-victim -that is, children involved in bullying as a perpetrator and a victimsignificantly showed lower SWB than children who were victims only or children who were not involved in bullying (Firdaus \& Borualogo, 2020). However, no studies have explained the SWB of perpetrators, whether in international studies or Indonesia. This becomes interesting to investigate, considering that bullying occurs because of perpetrators and victims' existence, so research on bullying should conduct a comprehensive study of both the perpetrator and the victim.

Casas (2016) stated three strong predictors of children's SWB: perception of safety, bullying, and respect for children that children perceived being adequately heard by parents. Children's perception of being adequately heard by parents is a form of respect and concern from parents for problems conveyed by children and being adequately heard by parents increases children's SWB (Corominas et al., 2020). Park (2004) stated that SWB is an important component for the positive development of children. 
Bullying is a social-ecology phenomenon that happens as the dynamic interplay between individual and environmental factors (Espelage \& Swearer, 2009; Hong et al., 2014; Swearer \& Espelage, 2004; Swearer et al., 2012). According to Bronfenbrenner (1986), family as a microsystem component contributes to the children's development directly and immediately. Parenting is one of the components that determine children's development. The dynamics between parenting in the microsystem (family) and how children perceive the parenting styles will determine a child's development process. The dynamic interplay between parents and children in the microsystem can predict children's bullying involvement (Espelage \& Swearer, 2009; Hong et al., 2014; Swearer \& Espelage, 2004; Swearer et al., 2012).

Bullied children tend to tell parents rather than teachers (Borualogo et al., 2020a; Fekkes et al., 2005). Parents are perceived as the source of main social support when children being victimised at school (Borualogo et al., 2020a). Parenting styles, as one of the microsystem components (Bronfenbrenner, 1986), is a predictor of school bullying (Borualogo et al., 2020b). Parenting styles and communication between parents and children correlated with children involvement in bullying, whether as the perpetrator and as the victim (Georgiou, 2008; Georgiou \& Stavrinides, 2008; Lereya et al., 2013). Perpetrators have rejective parents who tend to use violence in rearing their children (Georgiou \& Stavrinides, 2008). Overprotective parents and rejective parents strongly correlated with children being victimised at school (Lereya et al., 2013). Likewise, parents who do not supervise their children, are less warm and are inconsistent in disciplining their children, correlated with children involved in bullying as perpetrators (Flouri \& Buchanan, 2003; Kawabata et al., 2011).

Several studies have shown the contribution of parenting styles on children's involvement in bullying, but international studies still debated the contribution of parenting styles on SWB. Several studies explained a positive correlation between parenting styles and children's SWB (Dinisman et al., 2017; Gherasim et al., 2017; Wu et al., 2020), while other studies explained a negative correlation between parenting styles and SWB that depends on age, gender, and personality of the parents and children (Fan et al., 2020; Filus et al., 2019; Horton, 2020). This debate becomes an interesting topic for further study, particularly in the Indonesian context that is different from the Western context, where the studies were conducted. Moreover, there is no study investigating the contribution of parenting styles to SWB and children's perception that they are adequately heard, particularly on children involved in bullying, whether as the perpetrators or the victims.

This study used parenting theory from Perris and Perris (1978) that explained parenting in the context of children's deprivation. The parent-child relationship is an important determinant for children's development, whether they will successly developed or having developmental disorders. Perris and Perris (1978) explained three parenting styles: overprotective, warm, and rejective. Muris et al. (2003) modified Perris and Perris' (1978) parenting theory and added one parenting style: anxious parenting. Therefore, Muris et al. (2003) explained four parenting styles: warm parents, rejective 
parents, overprotective parents, and anxious parents. This concept from Muris et al. (2003) was used in this current study.

This parenting theory is one of the most used to explain parenting in the context of children' developmental disorders and children's mental health. For examples, children with Obsessive-Compulsive Disorder (OCD) (Mathieu et al., 2020), the mental health of Syrian refugee children (Eruyar et al., 2020), psychological distress (Temel \& Atalay, 2018), anxious children (Muris et al., 2000), and adolescent' aggression problem (Mukhtar \& Mahmood, 2018).

Based on the explanation above, current study investigated parenting styles' contribution to children's perception of being adequately heard and to SWB of school bullying perpetrators, victims and the uninvolved students in bullying. This study was essential due to the limited information on parenting styles' contribution to children's perception of being adequately heard and the SWB of the perpetrators and the victims; and limited studies on bullying perpetrators.

Therefore, this study attempted to fill the gap in the scientific literature by contributing to the understanding of the contribution of parenting styles to children's perception of being adequately heard and to the SWB of the perpetrators, the victims, and the uninvolved of elementary and middle school students who are the most vulnerable ages to be involved in bullying (Borualogo et al., 2020a, 2020b). By knowing parenting styles' contribution to children's perception of being adequately heard and SWB, preventing bullying can be made, both preventing being perpetrators and victims for elementary and middle school students.

\section{Method}

\section{Sample}

To obtain a representative sample of school bullying in Bandung City, West Java Province, samples were elementary and middle school students in Bandung City from 4 school types: private, public, religious-based, and non-religious based schools. A stratified cluster random sampling procedure was used, where the rank of the school was the strata, and the school type was the cluster. Therefore, all school types from all ranks were represented by random choice.

The researcher obtained a complete list of elementary and junior high school students in Bandung City from the Bandung City Education Office. With an estimated population proportion and a $95 \%$ confidence coefficient, to obtain a representative sample size, the Slovin formula is used (Almeda et al., 2010). A minimum of 400 samples is required at each level of education (elementary and middle schools). 11 elementary and 10 middle schools were selected randomly to represent a sample of elementary and middle school students in Bandung City. The sample size of elementary school students who participated in this study was 809 , and the sample size of middle school students who 
participated in this study was 845 . Due to the bullying group categorisation, each group's sample size was different from the study's total sample size.

The categorisation of research samples, including the perpetrators and the victims, was carried out by measuring the perpetrators of bullying and the bullying victims. Based on the definition of bullying as repeated aggressive behaviour aimed at hurting others because of the power imbalance between the perpetrator and the victim (Espelage \& Swearer, 2003; Olweus, 1997), the criterion for being a perpetrator and a victim is repetitive behaviour. Students who reported being bullied twice or more in the past month in at least one of the three categories of bullying (physical, verbal, and psychological) were included in the victim group. Meanwhile, students who bullied others two or more times in the past month in at least one of the three categories of bullying (physical, verbal, and psychological) were included in the perpetrator group.

\section{Procedure}

\section{Ethical clearance}

Approval for the study was gained from the ethical committee at Universitas Padjadjaran, Bandung and Nusantara Scientific Psychology Consortium. Permission to conduct the research in Bandung City was obtained from the Bandung City Education Office and Bandung City Political and National Unity Agency.

Written consent from parents was obtained on behalf of the students. The students were informed that they were free not to answer the questions and that their data will be treated confidentially.

\section{Research variables}

Parenting is an independent variable which its contribution to children's perceptions of being adequately heard by parents and its contribution to SWB of perpetrators, victims, and the uninvolved in bullying was analysed.

\section{Measurements}

All measurements used in this study had been adapted in the Indonesian context following cross-cultural psychology measurements adaptation guidance from van de Vijver (2019) and Borualogo et al. (2019).

\section{Perpetrator questionnaire}

Ten items measure perpetration were adopted from Cole et al. (2006) and translated into the Indonesian language considering the Indonesian context (Borualogo et al., 2019). These items measure the frequency of students' involvement in perpetration at school in the last month. Four items measure physical bullying (e.g., "I intentionally hit other kid"), 4 items measure verbal bullying (e.g., "I called other children with bad names"), and 2 items measure psychological bullying (e.g., "I forbade other children to befriend with certain kids"). These items were scored on a 4-point frequency scale using response 
options: never $=0$, once $=1,2$ or 3 times $=2$, and more than 3 times $=3$. The Cronbach's Alpha $=0.830$

\section{Bullying victim questionnaire}

Three items measure school bullying are from the Children's Worlds project (www.isciweb.org) that have been translated into the Indonesian language considering Indonesian contexts (Borualogo et al., 2019). School bullying was measured by frequency of physical bullying experiences ("How often in the last month have you been hit by other children in school?"), verbal bullying ("How often in the last month have you been called unkind names by other children in school?"), and psychological bullying ("How often in the last month have you been left out by other children in your class?"). These items were scored on a 4-point frequency scale using four response options: never $=0$, once $=1,2$ or 3 times $=2$, and more than 3 times $=3$. The Cronbach's Alpha $=0.847$

\section{Children's Worlds Subjective Well-Being Scale}

Children's Worlds Subjective Well-Being Scale (CW-SWBS) is a 6-item context-free psychometric scale modified by Children's Worlds (Rees \& Main, 2015) based on Student's Life Satisfaction Scale (SLSS) that developed by Huebner (1991). CW-SWBS has been adapted and showed excellent validation to use in Indonesia with 5 items (Borualogo \& Casas, 2019a). Details about the CW-SWBS and the Indonesian context's adaptation process can be read in an article written by Borualogo and Casas (2019a).

The items use an 11-point scale from 0 (not at all agree) to 10 (totally agree). The items are: (1) 'I enjoy my life', (2) 'My life is going well', (3) 'I have a good life', (4) 'The things that happen in my life are excellent, and (5) 'I am happy with my life'.

The CW-SWBS showed excellent fit (Borualogo \& Casas, 2019a). Fit indices are as follows: $\chi 2=94.58, \mathrm{df}=5, \mathrm{p}=0.000$, comparative fit index $(\mathrm{CFI})=0.988$, dan root mean square error of approximation $($ RMSEA) $=0.049(0.041-0.058)$ (Borualogo \& Casas, 2019a). The Cronbach's Alpha $=0.902$.

\section{Perception of being adequately heard by parents}

The Children's Worlds includes a single item to measure children's perception of being adequately heard by parents in their family relationship (Rees et al., 2020). The item is "My parents listen to me and take what I say into account". This item uses a 5-point scale: I do not agree $=1$, I agree a little $=2$, I agree somewhat $=3$, I agree a lot $=4$, and I totally agree $=5$.

\section{Egna Minnen Beträffande Uppfostran for Children}

Parenting styles were measured using The Egna Minnen Beträffande Uppfostran for Children (EMBU-C; Muris et al., 2003). The EMBU-C has value as a clinical tool for assessing parental factors that contribute to children's developmental disorders (Young et al., 2013). Although theory and measurement using the EMBU-C are popular in 
international studies related to parenting styles and children's problems, this theory is not popular in Indonesia. This theory is chosen regarding the contexts of parenting styles related to children's problems: bullying. The EMBU-C has been proven psychometrically able to explain perceived parenting styles in the context of children with problems (Deković, 2006; Markus et al., 2003; Young et al., 2013).

Egna Minnen Beträffande Uppfostran for Children (EMBU-C; Muris et al., 2003) was a modified version of the original EMBU that measure children's perception on parenting styles. This questionnaire has been adapted into Indonesian context (Borualogo \& Jefferies, 2021) and showed an excellence validation with fit indices for 4 models factor for father where: $\chi^{2}=2218.21, d f=696, p<0.001$, CFI $=0.91$, and RMSEA $=.05(.05-.06)$ and 4 model factors for mother where $\chi^{2}=2257.67, d f=696, p<0.001, \mathrm{CFI}=0.92$, and RMSEA $=$ $0.05(0.05-0.06)$. The Cronbach's Alpha Overprotective scale $=0.825$; for Warm scale $=$ 0.909; for Rejective scale $=0.874$; and for Anxious scale $=0.930$.

The questionnaire includes 40 items to measure 4 parenting styles: Overprotective parents (e.g.," Your parents think that they must decide everything for you"), Warm parents (e.g." When you are unhappy, your parents calm you down and cheer you up"), Rejective parents (e.g." Your parents say that they do not like your behaviour at home"), and Anxious parents (e.g." Your parents are worried about what you do after school").

Children answered each question separately for father and mother. These items use a 4-point scale: never $=1$, sometimes $=2$, often $=3$, and most of the time $=4$. Scoring for the EMBU-C had been done separately based on children's answer on father and mother for four parenting styles: Overprotective, Warm, Rejective, and Anxious.

\section{Data refinement}

Data refinement procedures in this current study were conducted in three steps. First, cases with incomplete questionnaires were deleted from the dataset. Second, children who reported not having parents or only have one parent were also deleted from the dataset. Third, the study followed the recommendation from Casas (2016), that cases with three or more missing values in the SWB scale should be eliminated for further analysis. There were 360 cases deleted from the dataset.

\section{Data analysis}

Data were analyzed using linear regression to test the contribution of parenting styles to children's perception (in the three groups: perpetrator, victim, and the uninvolved) of being adequately heard, and to test the contribution of parenting styles to SWB indicators in those three groups. Descriptive statistics had been calculated to test the mean differences in parenting styles, the perception that children being adequately heard, and SWB indicators to test significant differences between three groups and gender. Data were calculated using SPSS 23. 


\section{Results}

Table 1.

Characteristics of Participants

\begin{tabular}{lcccccccc}
\hline & \multicolumn{2}{c}{ Perpetrator } & \multicolumn{2}{c}{ Victim } & \multicolumn{2}{c}{ The Uninvolved } & \multicolumn{2}{c}{ Total } \\
\cline { 2 - 9 } & $\mathbf{n}$ & $\mathbf{\%}$ & $\mathbf{n}$ & $\mathbf{\%}$ & $\mathbf{n}$ & $\mathbf{\%}$ & $\mathbf{n}$ & $\mathbf{\%}$ \\
\hline Girls & 51 & 41.5 & 338 & 58.7 & 320 & 53.8 & 709 & 54.8 \\
Boys & 72 & 58.5 & 238 & 41.3 & 275 & 46.2 & 585 & 45.2 \\
Elementary & 28 & 22.8 & 329 & 57.1 & 255 & 42.9 & 612 & 47.3 \\
Middle & 95 & 77.2 & 247 & 42.9 & 340 & 57.1 & 682 & 52.7 \\
Total & 123 & 100 & 576 & 100 & 595 & 100 & 1,294 & 100 \\
\hline
\end{tabular}

Table 1 shows that perpetrators are mostly boys (58.5\%), and victims are mostly girls (58.7\%). According to education level, perpetrators are mostly middle school students $(77.2 \%)$, while elementary school students are mostly victims (57.1\%). Table 2 shows descriptive data of mean scores of SWB, children's perception of being adequately heard, and perception of parenting styles by gender for three groups of bullying incidents.

For the three groups of bullying incidents, the highest mean score of parenting styles for both girls and boys were observed for warm mothers. The girl and boy perpetrators displayed the lowest SWB scores across the three groups. The girl victims and the boy perpetrators displayed the lowest SWB scores on how they perceived of being adequately heard across the three groups. The anxious mothers and anxious fathers were perceived significantly different by boys and girls from the victim group and the uninvolved group. For the victim group and the uninvolved group, girls displayed higher mean scores on perceiving anxious mothers and anxious fathers than boys.

For the perpetrator group, there were no significant differences between boys and girls on perceiving parenting styles, SWB mean scores, and perceived being adequately heard. For the victim group, girls displayed significantly higher mean scores on perceiving overprotective mothers, anxious mothers, and anxious fathers than boys. For the uninvolved group, the SWB mean scores are the highest across two groups: the perpetrator and the victim groups. Boys and girls displayed significant differences in perceived parenting styles, except for rejective mothers that showed no differences between boys and girls. Girls displayed higher mean scores on perceiving parenting styles than boys, except for perceived rejective fathers. 
BORUALOGO || THE ROLE OF PARENTING STYLE

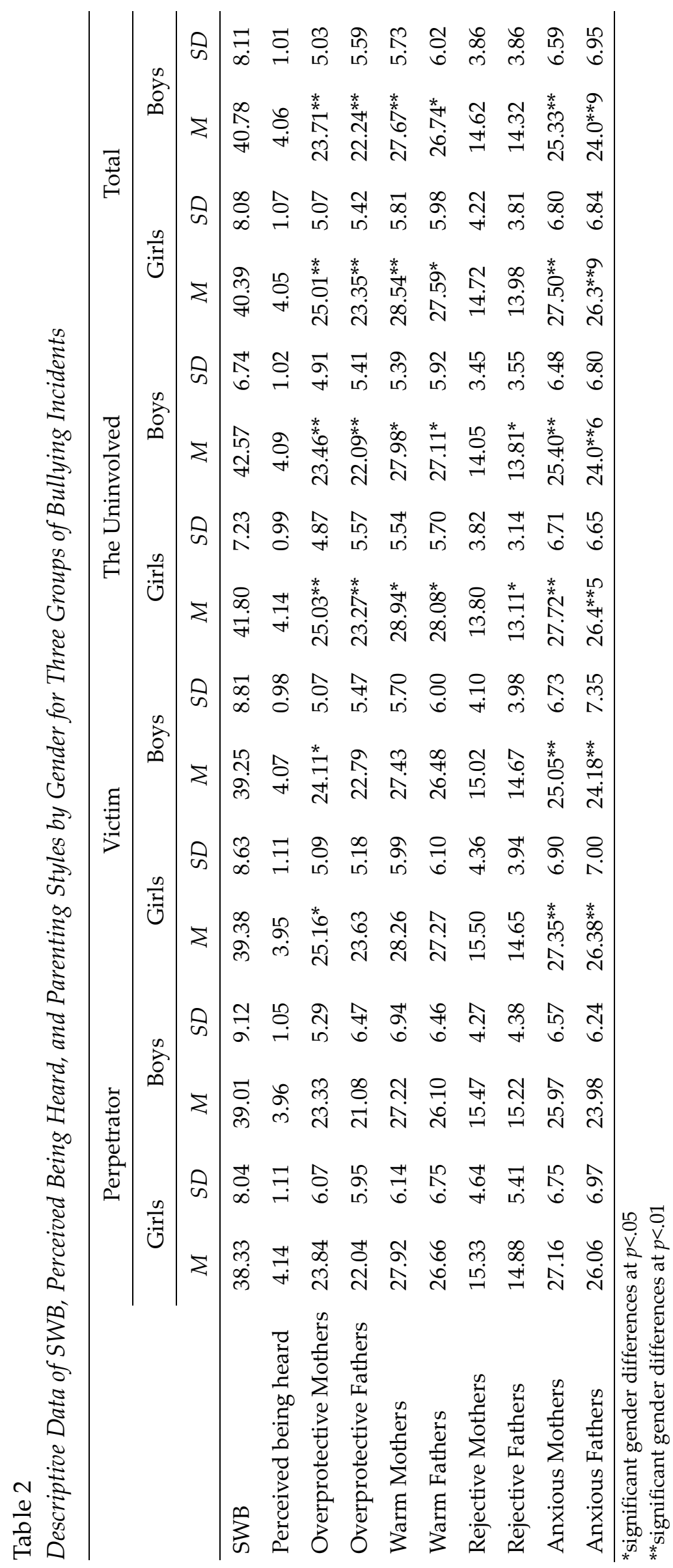


Table 3.

Descriptive Data of SWB, Perceived Being Heard, and Parenting Styles for Perpetrator, Victim, and the Uninvolved

\begin{tabular}{lcccccccc}
\hline & \multicolumn{2}{c}{ Perpetrator } & \multicolumn{2}{c}{ Victim } & \multicolumn{2}{c}{ The Uninvolved } & \multicolumn{2}{c}{ Total } \\
\cline { 2 - 9 } & $\boldsymbol{M}$ & $S D$ & $\boldsymbol{M}$ & $S D$ & $\boldsymbol{M}$ & $S D$ & $\mathbf{M}$ & SD \\
\hline SWB & $38.73^{* *}$ & 8.66 & $39.32^{* *}$ & 8.69 & $42.16^{* *}$ & 7.01 & 40.57 & 8.09 \\
Perceived being heard & 4.03 & 1.07 & 4.00 & 1.06 & 4.11 & 1.01 & 4.01 & 1.08 \\
Overprotective Mothers & $23.54^{*}$ & 5.60 & $24.72^{*}$ & 5.11 & 24.31 & 4.95 & 24.48 & 5.06 \\
Overprotective Fathers & $21.47^{* *}$ & 6.25 & $23.29^{* *}$ & 5.31 & $22.72^{*}$ & 5.52 & 22.89 & 5.56 \\
Warm Mothers & 27.50 & 6.61 & 27.92 & 5.89 & 28.49 & 5.49 & 27.98 & 5.83 \\
Warm Fathers & $26.34^{*}$ & 6.56 & 26.95 & 6.07 & $27.63^{*}$ & 5.82 & 26.97 & 6.03 \\
Rejective Mothers & $15.41^{* *}$ & 4.40 & $15.30^{* *}$ & 4.26 & $13.92^{* *}$ & 3.65 & 15.09 & 4.27 \\
Rejective Fathers & $15.07^{* *}$ & 4.82 & $14.66^{* *}$ & 3.95 & $13.43^{* *}$ & 3.35 & 14.62 & 4.14 \\
Anxious Mothers & 26.45 & 6.64 & 26.40 & 6.9 & 26.65 & 6.70 & 26.54 & 6.73 \\
Anxious Fathers & 24.85 & 6.60 & 25.49 & 7.22 & 25.34 & 6.82 & 25.29 & 6.87 \\
\hline
\end{tabular}

*significant gender differences at $\mathrm{p}<.05$

**significant gender differences at $\mathrm{p}<.01$

Table 3 shows significant differences in the SWB mean scores by three groups of bullying incidents. The uninvolved group displayed the highest SWB mean scores, while the perpetrator group displayed the lowest SWB mean scores. There were no significant differences in perceived being adequately heard for the three groups. Perceived rejective mothers and rejective fathers displayed significant differences across three groups. The mean scores of perceived rejective fathers and rejective mothers were significantly lower for the uninvolved group than the perpetrator group and victim group. Perceived warm fathers significantly displayed higher mean scores for the uninvolved group than the perpetrator group. Perceived overprotective fathers displayed significant differences across perpetrator group and victim group $(p<0.01)$, and across perpetrator group and the uninvolved group $(p<0.05)$, where the perpetrator group displayed lower mean scores. Perceived overprotective mothers displayed significant differences across perpetrator group and victim group, where the victim group displayed lower mean scores.

Table 4 shows the significant contribution of parenting styles to children's perception of being adequately heard by parents and SWB for three groups by gender. There was no significant contribution of parenting styles on perpetrator girls and victim boys, whether on children's perception being adequately heard by parents and their SWB.

For the boy perpetrators, the rejective mothers contributed negatively to children's perception of being adequately heard $(\beta=-0.593 ; p<0.05)$. In contrast, rejective fathers contributed positively $(\beta=0.642 ; p<0.05)$ to children's perception of being adequately heard. These two parenting styles contributed as many $13.4 \%$ to children's perception of being adequately heard. For boy perpetrators, rejective fathers contributed negatively ( $\beta=$ $-0.515 ; p<0.05)$ as many as $17.7 \%$ to SWB. 
Table 4.

Linear Regression of Parenting Styles on SWB and Perceived Being Adequately Heard in the Three Groups by Gender

\begin{tabular}{|c|c|c|c|c|c|c|}
\hline Variables & $B$ & $S E$ & $\beta$ & $t$ & $p$ & Adjusted $\mathrm{R}^{2}$ \\
\hline & \multicolumn{6}{|c|}{ Boy perpetrators } \\
\hline \multicolumn{7}{|l|}{ Being adequately heard } \\
\hline Rejective Mothers & -.146 & .066 & -.593 & -2.206 & .031 & . 134 \\
\hline Rejective Fathers & .157 & .063 & .642 & 2.483 & .016 & .134 \\
\hline \multicolumn{7}{|l|}{ SWB } \\
\hline Rejective Fathers & -2.167 & 1.060 & -.515 & -2.044 & .045 & .177 \\
\hline & \multicolumn{6}{|c|}{ Girl victims } \\
\hline \multicolumn{7}{|l|}{ Being adequately heard } \\
\hline & \multicolumn{6}{|c|}{ The uninvolved boys } \\
\hline $\begin{array}{l}\text { Being adequately heard } \\
\text { Warm Mothers }\end{array}$ & .069 & .031 & .369 & 2.208 & .028 & .105 \\
\hline \multicolumn{7}{|l|}{ SWB } \\
\hline Warm Mothers & .985 & .406 & .398 & 2.425 & .016 & .132 \\
\hline Anxious Mothers & -.773 & .369 & -.374 & -2.097 & .037 & .132 \\
\hline Anxious Fathers & .705 & .353 & .355 & 1.995 & .047 & .132 \\
\hline & \multicolumn{6}{|c|}{ The uninvolved girls } \\
\hline $\begin{array}{l}\text { Being adequately heard } \\
\text { Warm Mothers }\end{array}$ & .108 & .023 & .583 & 4.783 & .000 & .207 \\
\hline \multicolumn{7}{|l|}{ SWB } \\
\hline Overprotective Fathers & 1.169 & .358 & .387 & 3.269 & .001 & .266 \\
\hline Warm Mothers & 1.084 & .317 & .403 & 3.423 & .001 & .266 \\
\hline Rejective Mothers & -.996 & .374 & -.260 & -2.666 & .008 & .266 \\
\hline Anxious Mothers & -.628 & .246 & -.288 & -2.553 & .011 & .266 \\
\hline
\end{tabular}

For girl victims, warm mothers contributed positively $(\beta=0.513 ; p<0.05)$ as many as $23.7 \%$ to children's perception of being adequately heard. For the uninvolved group, both for boys and girls, warm mothers contributed positively to the children's perception of being adequately heard. For the uninvolved boys, warm mothers contributed positively ( $\beta$ $=0.369 ; p<0.05)$ as many as $10.5 \%$, while for the uninvolved girls, warm mothers contributed positively $(\beta=0.583 ; p<0.05)$ as many as $20.7 \%$.

Parenting styles contributed differently to SWB of the uninvolved group, both for boys and girls. Warm mothers $(\beta=0.398 ; p<0.05)$ and anxious fathers $(\beta=0.355 ; p<0.05)$ contributed positively as many as $13.2 \%$ to SWB of the uninvolved boys. While anxious mothers contributed negatively $(\beta=-0.374 ; p<0.05)$ as many as $13.2 \%$ to SWB of the uninvolved boys.

For the uninvolved girls, overprotective fathers $(\beta=0.387 ; p<0.05)$ and warm mothers $(\beta=0.403 ; p<0.05)$ contributed positively as many as $26.6 \%$ to SWB. While rejective mothers $(\beta=-0.260 ; p<0.05)$ and anxious mothers $(\beta=-0.288 ; p<0.05)$ contributed negatively as many as $26.6 \%$ to SWB. 


\section{Discussion}

This current study showed that parenting styles play different roles to children's perception of being adequately heard and to their SWB, depending on the gender and their involvement in bullying. This discussion will explain the role of parenting styles on children's perception of being adequately heard and their SWB for each group.

This study also showed that children who do not involve in bullying displayed the highest mean scores of SWB than children from two other groups. These results confirmed previous studies showing mean scores of SWB of children not involved in bullying were significantly higher than SWB of bullied children (Borualogo \& Casas, 2019b; Savahl et al., 2019; Tiliouine, 2015). Because there is no research on the SWB of the perpetrators, this study's results provide new information about the low SWB of perpetrators, even lower than the SWB of victims. This result needs to be taken into account for parents and teachers because the lowest SWB of perpetrators indicates severe problems and potential negative consequences in the children's development, so prevention efforts need to be made.

For the three groups, children perceived parenting styles differently that was shown by the highest mean scores of parenting styles across three groups (Table 3). For the uninvolved group, children perceived their parents were warm. For the victim group, children perceived their parents as overprotective parents. As for the perpetrator group, children perceived their parents as rejective parents. These results are in line with previous studies that explained victimized children come from a family with overprotective parents (Lereya et al., 2013), while the uninvolved children come from families with warm parents (Miranda et al., 2015). These results were in line with Georgiou and Stavrinides' (2008) findings that perpetrators come from a family with rejective parents. However, a recent study from Stavrinides et al. (2018) is not in line with this study's findings. Stavrinides et al. (2018) showed that parents who reject their children do not predict children's behaviour as perpetrators. The difference in the results of these findings is debatable for following up in the next research.

There are no significant differences in children's perception of being adequately heard by parents (Table 3). This finding indicates that children from three groups perceived that parents listen to them and not correlate to their bullying involvement. However, parenting styles play different roles in children's perception of being adequately heard by parents (Table 4 ).

\section{The uninvolved group}

Warm mothers play positively to boys' and girls' perception of being adequately heard by mothers (Table 4). Warm mothers care for children, appreciate children's positive behaviour, and express affection and love (Veenstra et al., 2005). Warm mothers accept their children for who they are, listen to, respect for children's opinions, express affection, give compliments, cheer them up, offer help when the children are facing obstacles, and when children make mistakes, children can fix it together with parents (Muris et al., 2003). 
In the Indonesian context, mothers play a role as a source of affection at home (Zevalkink \& Riksen-Walraven, 2001) and are perceived more authoritative than fathers by children and youth (Abubakar et al., 2014). In general, Indonesian mothers display supportive behaviours and warmth in their reciprocal relationships with their children that are important for stimulating children's social and emotional development (Mulder, 1992; Setiadi, 2006). Therefore, warm mothers were perceived as mothers who listen to children adequately.

Warm mothers play a greater role for girls $(20.7 \%)$ than boys $(10.5 \%)$ on how they perceived being adequately heard by mothers (Table 4$)$. This happens because boys tend to seek more autonomy from parents than girls (Abubakar et al., 2014; Leaper, 2002), although boys still positively perceived their mothers' care and warm while communicating at home.

Warm mothers significantly contributed positively to the SWB of the uninvolved boys and girls. Warm mothers were perceived as giving special attention and express affection toward their children (Veenstra et al., 2005). Warm mothers allow their children to share their feelings and experiences; and allow their children to seek help when needed. These results confirmed studies by Garbarino (2014), Houltberg et al. (2016), and Panetta et al. (2014) that warm parents contributed to children's SWB. Warm mothers also contributed positively to the uninvolved boys and girls where they perceive being adequately heard. Therefore, warm mothers play an essential role in children's SWB and children's perception that mothers adequately listen to them.

The uninvolved children displayed the highest mean SWB scores than the two other groups (Table 3$)$, where boys $(M=85.13)$ displayed higher mean SWB score than girls $(M$ $=83.60$ ) (Table 2). The effect of gender on children's SWB is still debating. Several studies showed that gender contributed to children's SWB (Borualogo \& Casas, 2019b), while several other studies still questioning the effect of gender on SWB (Savahl et al., 2019). Therefore, it is interesting to investigate this issue further.

Other interesting findings from this current study showed that anxious fathers contributed positively to the SWB of the uninvolved boys, while overprotective fathers contributed positively to the SWB of the uninvolved girls (Table 4). Anxious fathers express worried about things that children do after school, worried that something terrible will happen to children, and worried that children might get into troubles or do dangerous things (Muris et al., 2003). Meanwhile, overprotective fathers obliged children to tell the fathers what children have done, determined what children may or may not do, and control all children's activities (Muris et al., 2003).

In the Indonesian context, the father is the head of the family and responsible for protecting and controlling their children (Zevalkink \& Riksen-Walraven, 2001). Fathers were perceived as a figure who keeps an emotional distance from their children to enforce the rule and disciple children at home (Zevalkink \& Riksen-Walraven, 2001). Therefore, children's perception of overprotective fathers contributed positively to children's SWB. Children perceived that fathers play roles to control and protect their children, ensuring 
children's development and protecting them. They also perceived that their fathers play the role that the fathers should play.

Anxious mothers contributed negatively to the SWB of the uninvolved boys and girls, while the rejective mothers contributed negatively to the SWB of the uninvolved girls (Table 4). Rejective mothers blame children for things that happen at home, criticize children, and punish children without reason (Muris et al., 2003). Therefore, children perceive that mothers did not adequately listen to them. Meanwhile, anxious mothers express excessive worry; they worry that their children might get into trouble or do dangerous things (Muris et al., 2003). Children are not free to carry out their activities and feel that mothers did not adequately listen to them because their opinions cause excessive worry in their mothers.

Results in the uninvolved group explained the living conditions of children in normal situations without exposure to violence. Different things happen to perpetrators and victims.

\section{Perpetrator group}

For the boy perpetrators, both rejective mothers and rejective fathers contributed to children's perception of being adequately heard by parents (Table 4). Rejective mothers contributed negatively to boys' perception of being adequately heard by mothers, while rejective fathers contributed positively to boys' perception that fathers adequately listen to them. These are interesting findings because parents of perpetrator tend to reject their children (Demaray \& Malecki, 2003) and do not provide adequate social support (Low \& Espelage, 2014). However, the difference in the role of rejective fathers and mothers on children's perception of being adequately heard is interesting for further study.

Rejective mothers blame children for everything that should not have happened, treat children unfairly, punish children for no reason, and show that they do not like their children (Muris et al., 2003). Rejective mothers prevent boy perpetrators from sharing experiences or telling their involvement in bullying because children are afraid of receiving punishment and being more rejected by their mothers. Children's perceived that mothers do not listen to their opinions about things that happen in children's lives and do not take them as seriously as expected by children. This is in line with Demaray and Malecki's (2003) study that parents of perpetrators tend to physically punish and reject their children. In the Indonesian context, rejective mothers were perceived as incompatible with the traditional role of warm and affectionate mothers (Abubakar et al., 2014), therefore children prefer not to tell their behaviour at school as the perpetrators. A study that had been done by Sumargi et al. (2015) showed that parents of children with behaviour problems tend to use ineffective parenting strategies when dealing with children misbehavior; for example, they do not communicate the misbehavior with children and tend to shout to express disagreement. Indonesian parents of children with behavioural problems showed less confidence, higher stress level, and less support from partner in parenting their children (Sumargi et al., 2015). Rejection from mothers to boy 
perpetrators and mothers' reluctance to adequately listen to their childrenincrease the risk for children to involve in more serious perpetration (Estévez et al., 2007). Furthermore, this study showed that the SWB of perpetrators were the lowest compared to the two other groups (Table 3). Mothers shall appreciate children's feelings, accept children's emotional conditions, and talk with children about the consequences of their behaviour and its effect on others' feelings.

In contrast, rejective fathers contributed positively to boy perpetrators' perception of communication with fathers. This may relate to the Indonesian context, where fathers tend to keep an emotional distance from their children to instill discipline (Zevalkink \& Riksen-Walraven, 2001). Therefore, while boys become perpetrators, they perceive fathers' emotional distance as a form of disagreement to their perpetration behaviour. Fathers do not have to express disagreement verbally, but fathers' rejection was perceived as an adequate response to boys' perpetration behaviour. However, rejective fathers contributed negatively to the SWB of boy perpetrators (Table 4). Although boys perceived fathers' rejection as a form of non-verbal communication to express disagreement, fathers' rejection caused unpleasant conditions for perpetrators and contributed negatively to their SWB.

\section{Victim group}

For the girl victims, warm mothers contribute to children's perception that mothers adequately listen to them. Warm mothers express positive emotions in communicating with their children, particularly when children were being victimized. Children perceive that mothers understand their problems; therefore, children are willing to talk to mothers about their bullying experiences. This is in line with the Indonesian concept of mother as a warm figure who supports and cares for the family and takes care of their children in their daily lives (Abubakar et al., 2014; Setiadi, 2006). In taking care of their children, mothers show warm and listen to children's complaint about anything.

\section{Conclusion}

Parenting styles play different roles in children's perception of being adequately heard and their SWB, depending on children's involvement in bullying and gender. Results showed that parents were perceived differently in parenting across the three groups. The uninvolved group perceived that parents were warm. The perpetrator group perceived that parents were rejective. The victim group perceived that parents were overprotective.

Perpetrators displayed the lowest SWB scores than victims and the uninvolved. This indicates that perpetrators have serious problems that need to be attended by parents and teachers so they can get help immediately. Warm mothers and overprotective fathers play positive roles in children's SWB. This had not happened in the perpetrator group and victim group. Therefore, this also needs to be seriously taken into account by parents. Parents were suggested to express warm and to protect children for increasing children's SWB. 
This study's results strongly indicate that the mother is perceived as a warm figure; someone who listens to children's adequately and contributes to children's SWB. This study's results can help perpetrators and victims to receive warm parenting to help increase their SWB. A child who displays low SWB indicates that the child is experiencing serious problems. Therefore, they need to get immediate help to prevent more critical problems. This is particularly evident in the perpetrator group.

This study had some limitations. The focus of this study was only on the perpetrator, the victim, and the uninvolved. Other studies have shown that the perpetrator-victim group is believed to have lower SWB than two other groups studied here. Therefore, in a future study, it is suggested to investigate this perpetrator-victim group.

\section{Implication}

Based on this study, it is suggested that parents express warmth while listening to their children adequately, both in the normal condition while children do not have any problems, moreover in the condition while children involved in bullying. Warm parents play an important role in increasing children's SWB, either when children face bullying problems at school as perpetrators or victims.

Perpetrators displayed the lowest SWB across three groups. This indicates that perpetrators were facing serious problems. Therefore, the more serious negative consequences need to be prevented by providing help to the perpetrators.

\section{Acknowledgements}

Author would like to that the team who assisted the data collection and elementary and middle school students in Bandung City who participated in this study.

\section{Funding}

The author received no financial support for the research, authorship and or/publication of this article.

\section{Author's contribution}

The author designed the research, supervised data collection, analyzed the data, and wrote the manuscript.

\section{Conflict of Interest}

The author declares that she has no conflict of interest.

\section{Orcid ID}

Ihsana Sabriani Borualogo 0000-0002-8590-9701 


\section{References}

Abubakar, A., Van de Vijver, F. J. R., Suryani, A.O., Handayani, P., \& Pandia, W. S. (2014). Perceptions of parenting styles and their associations with mental health and life satisfaction among urban Indonesian adolescents. Journal of Child and Family Studies, 24, 2680-2692. https://doi.org/10.1007/s10826-014-0070-x

Alcantara, S., González-Carrasco, M., Montserrat, C., Viñas, F., Casas, F., \& Abreu, D. P. (2017). Peer violence in the school environment and its relationship with subjective well-being and perceived social support among children and adolescents in Northeastern Brazil. Journal of Happiness Studies, 18, 1507-1532. https://doi.org/10.1007/s10902-016-9786-1

Almeda, J.T., Capistrano, T., \& Sarte, G. (2010). Elementary statistics. UP Press

Borualogo, I. S., \& Casas, F. (2019a). Adaptation and validation of the Children's Worlds Subjective Well-Being Scale (CW-SWBS) in Indonesia. Jurnal Psikologi, 46, 102-116. https://doi.org/10.22146/jpsi.38995

Borualogo, I. S., \& Casas, F. (2019b). Subjective well-being of bullied children in Indonesia. Applied Research in Quality of Life, 16, 753-773. https://doi.org/10.1007/s11482-01909778-1

Borualogo, I. S. \& Gumilang, E. (2019). Kasus perundungan anak di Jawa Barat: Temuan awal Children's Worlds Survey di Indonesia [Bullying cases in West Java: First findings of the Children's Worlds Survey in Indonesia]. Psympathic: Jurnal Ilmiah Psikologi, 6(1), 15-30. https://doi.org/10.15575/psy.v6i1.4439

Borualogo, I. S., Gumilang, E., Mubarak, A., Khasanah, A. N., Wardati, M. A., Diantina, F. P., Permataputri, I., \& Casas, F. (2019). Process of translation of the Children's Worlds Subjective Well-Being Scale in Indonesia. Proceedings of the Social and Humaniora Research Symposium (SoRes 2018), 307, 180-183. https://doi.org/10.2991/sores-18.2019.42

Borualogo, I. S., \& Jefferies, P. (2021). Adapting The EMBU-C for Indonesian contexts [Manuscript in preparation]. Faculty of Psychology Universitas Islam Bandung \& Resilience Research Centre, Dalhousie University.

Borualogo, I. S., Wahyudi, H., \& Kusdiyati, S. (2020a). Bullying victimisation in elementary school students in Bandung City. Proceedings of the Social and Humaniora Research Symposium (SoRes 2019), 409, 112-116. https://doi.org/10.2991/assehr.k.200225.024

Borualogo, I. S., Wahyudi, H., \& Kusdiyati, S. (2020b). Prediktor perundungan siswa sekolah dasar [Predictors of bullying in elementary school students]. Jurnal Imliah Psikologi Terapan, 8, 35-57. https://doi.org/10.22219/jipt.v8i1.9841

Bronfenbrenner, U. (1986). Ecology of the family as a context for human development: research perspectives. Developmental Psychology, 22(6), 723-742. https://doi.org/10.1037/0012-1649.22.6.723

Casas, F. (2016). Children, adolescents and quality of life: The social sciences perspective over two decades. In F. Maggino (Ed.), A Life Devoted to Quality of Life: Festschrift in 
honor of Alex C. Michalos (pp. 3-21). Springer. https://doi.org/10.1007/978-3-31920568-7_1

Cole, J.C.M., Cornell, D., \& Sheras, P. (2006). Identification of school bullies by survey methods. Professional School Counseling Journal, 9(4), 305-313. https://doi.org/10.1177\%2F2156759X0500900417

Corominas, M., González-Carrasco, M., \& Casas, F. (2019). The importance of feeling adequately heard by adults and enjoying time with family in relation to children's subjective well-being. Child Indicators Research, 13, 193-214. https://doi.org/10.1007/s12187-019-09680-0

Deković, M., ten Have, M., Vollebergh, W. A. M., Pels, T., Oosterwegel, A., Wissink, I. B., De Winter, A. F., Verhulst, F. C., \& Ormel, J. (2006). The cross-cultural equivalence of parental rearing measure: EMBU-C. European Journal of Psychological Assessment, 22(2), 85-91. https://doi.org/10.1027/1015-5759.22.2.85

Demaray, M. K., \& Malecki, C. K. (2003). Perceptions of the frequency and importance of social support by students classified as victims, bullies, and bully/victims in an urban middle school. School Psychology Review, 32(3), 471-489. https://tandfonline.com/doi/10.1080/02796015.2003.12086213

Dinisman, T., Andresen, S., Montserrat, C., Strózik, D., \& Strózik, T. (2017). Family structure and family relationship from the child well-being perspective: Findings from comparative analysis. Children and Youth Services Review, 80, 105-115. https://doi.org/10.1016/j.childyouth.2017.06.064

Eruyar, S., Maltby, J., \& Vostanis, P. (2020). How do Syrian refugee children in Turkey perceived relational factors in the context of their mental health? Clinical Child Psychology and Psychiatry, 25(1), 260-272. https://doi.org/10.1177/1359104519882758

Espelage, D. L, \& Hong, J. S. (2019). Children who bully or are bullied. In T. H. Ollendick, S. W. White, \& B. A. White (Eds.), The Oxford handbook of clinical child and adolescent psychology. Oxford Handbooks Online. https://doi.org/10.1093/oxfordhb/9780190634841.013.37

Espelage, D. L., \& Swearer, S. M. (2009). A social-ecological model for bllying prevention and intervention. In S. R. Jimerson, S. M. Swearer, \& D. L. Espelage (Eds.), Handbook of bullying in schools: An international perspective, (pp. 61-72). Routledge.

Espelage, D. L., \& Swearer, S. M. (2003). Research on school bullying and victimisation: What have we learned and where do we go from here? School Psychology Review, 32(3), 365-383. https://doi.org/10.1080/02796015.2003.12086206

Estévez, E., Murgui, S., Moreno, D., \& Musitu, G. (2007). Family communication styles, attitude towards institutional authority and adolescents' violent behaviour at school. Psicothema, 19(1), 108-113.

Fan, H., Li, D., Zhou, W., Jiao, L., Liu, S., \& Zhang, L. (2020). Parents' personality traits and children's subjective well-being: A chain mediating model. Current Psychology. https://doi.org/10.1007/s12144-020-01078-4 
Fekkes, M., Pijpers, F. I. M., \& Verloove-Vanhorick, S. P. (2005). Bullying: Who does what, when and where? Involvement of children, teachers and parents in bullying behavior. Health Education Research, 20, 81-91. https://doi.org/10.1093/her/cyg100

Filus, A., Schwarz, B., Mylonas, K., Sam, D. L., \& Boski, P. (2019). Parenting and late adolescents' well-being in Greece, Norway, Poland, and Switzerland: Associations with individuation from parents. Journal of Child and Family Studies, 28, 560-576. https://doi.org/10.1007/s10826-018-1283-1

Firdaus, R. T., \& Borualogo, I. S. (2020). Pengaruh pola asuh terhadap subjective wellbeing pada dua kelompok perundungan. Prosiding Psikologi Seminar Penelitian Sivitas Akademika Unisba, 6(2), 920-926. http://karyailmiah.unisba.ac.id/index.php/psikologi/article/view/24689

Fitzpatrick, S., \& Bussey, K. (2011). The development of the Social Bullying Involvement Scales. Aggressive Behavior, 37, 177-192. https://doi.org/10.1002/ab.20379

Flouri, E., \& Buchanan, A. (2003). The role of mother involvement and father involvement in adolescent bullying behavior. Journal of Interpersonal Violence, 18(6), 634-644. https://doi.org/10.1177/0886260503251129

Garbarino, J. (2014). Ecological perspectives on child well-being. In A. Ben-Arieh, F. Casas, I. Frones, \& J. E. Korbin (Eds.). Handbook of Child Well-Being: Theories, Methods and Policies in Global Perspective. (pp. 1365-1384). Springer. https://doi.org/10.1007/978-90481-9063-8_140

Georgiou, S. N. (2008). Parental style and child bullying and victimisation experiences at school. Social Psychology of Education, 11, 213-227. https://doi.org/10.1007/s11218-0079048-5

Georgiou, S. N., \& Stavrinides, P. (2008). Bullies, victims and bully victims' psychosocial profiles and attribution styles. School Psychology International, 29, 574-589. https://doi.org/10.1177/0143034308099202

Gherasim, L. R., Brumariu, L. E., \& Alim, C. L. (2017). Parenting style and children's life satisfaction and depressive symptoms: Preliminary findings from Romania, France, and Russia. Journal of Happiness Studies, 18, 1013-1028. https://doi.org/10.1007/s10902-016-9754-9

Hong, J. S., Peguero, A. A., Choi, S., Lanesskog, D., Espelage, D. L., \& Lee, N. Y. (2014). Social ecology of bullying and peer victimization of Latino and Asian youth in the United States: A review of the literature. Journal of School Violence, 13(3), 315-338. https://doi.org/10.1080/15388220.2013.856013

Horton, R. S. (2020). Parenthood, subjective well-being, and the moderating effects of parent narcissism. Journal of Individual Differences, 42(2), 57-63. https://doi.org/10.1027/1614-0001/a000329

Houltberg, B. J., Morris, A. S., Cui, L., Henry, C. S., \& Criss, M. M. (2016). The role of youth anger in explaining links between parenting and early adolescent prosocial and antisocial behavior. Journal of Early Adolescence, 36(3), 297-318. https://doi.org/10.1177\%2F0272431614562834 
Huebner, E. (1991). Initial development of the Student's Life Satisfaction Scale. School Psychology International, 12, 231-240. https://doi.org/10.1177/\%2F0143034391123010

Kawabata, Y., Alink, L. R. A., Tseng, W. L., van Ijzendoorn, M. H., \& Crick, N. R. (2011). Maternal and paternal parenting styles associated with relational aggression in children and adolescents: A conceptual analysis and meta-analytic review. Developmental Review, 31(4), 240-278. https://doi.org/10.1016/j.dr.2011.08.001

Kementerian Perencanaan Pembangunan Nasional (Bappenas) dan United Nations Children's Fund. (2017). Laporan baseline SDG tentang anak-anak di Indonesia [SDG Baseline report of Indonesian children]. BAPPENAS dan UNICEF.

Leaper C. (2002). Parenting girls and boys. In M.H. Bornstein. (Ed.), Handbook of parenting: Children and parenting (pp. 189-225). Lawrence Erlbaum Associates Publishers.

Lereya, S. T., Samara, M., \& Wolke, D. (2013). Parenting behavior and the risk of becoming a victim and a bully/victim: A metanalysis study. Child Abuse \& Neglect, 37(12), 1091-1108. https://doi.org/10.1016/j.chiabu.2013.03.001.

Low, S., \& Espelage, D. L. (2014). Conduits from community violence exposure to bullying and victimization: Contributions of parental monitoring, impulsivity and deviancy. Journal of Counseling Psychology, 61(2), 221-231. https://doi.org/10.1037/a0035207

Markus, M. T., Lindhout, I. E., Boer, F., Hoogendijk, T. H. G., \& Arrindell, W. A. (2003). Factors of perceived parental rearing styles: the EMBU-C examined in a sample of Dutch primary school children. Personality and Individual Differences, 34(3), 503-519. https://doi.org/10.1016/S0191-8869(02)00090-9.

Mathieu, S. L., Conlon, E. G., Walters, A. M., \& Farrell, L. J. (2020). Perceived parental rearing in pediatric obsessive-compulsive disorder: Examining the factor structure of the EMBU child and parent versions and associations with OCD symptoms. Child Psychiatry and Human Development, 51, 956-968. https://doi.org/10.1007/s10578-02000979-6.

Miranda, M. C., G. Affuso, C. Esposito, \& D. Bacchini. (2015). Parental AcceptanceRejection and Adolescent Maladjustment: Mothers' and Fathers' Combined Roles. Journal of Child and Family Studies, 25, 1352-1362. https://doi.org/10.1007/s10826-0150305-5.

Mukhtar, S., \& Mahmood, Z. (2018). Moderating role of perceived social support between perceived parenting styles and relational aggression in adolescents. Journal of Aggression, Maltreatment $\mathcal{E} \quad$ Trauma, 27(8), 831-845. https://doi.org/10.1080/10926771.2018.1468842.

Mulder, N. (1992). Individual and society in Java: A cultural analysis (2nd ed.). Yogyakarta, Indonesia: Gadjah Mada University Press.

Mullis, I. V. S., Martin, M. O., Foy, P., \& Hooper, M. (2016). TIMSS 2015 International research in mathematics. International Study Center Lynch School of Education Boston College. http://timssandpirls.bc.edu/timss2015/international-results/wpcontent/uploads/filebase/full\%20pdfs/T15-International-Results-in-Mathematics.pdf 
Muris, P., Meesters, C., Merckelbach, H., \& Hülsenbeck, P. (2000). Worry in children is related to perceived parental rearing and attachment. Behaviour Research and Therapy, 38(5), 487-497. https://doi.org/10.1016/S0005-7967(99)00072-8.

Muris, P., Meesters, C., \& van Brakel, A. (2003). Assessment of anxious rearing behavior with a modified version of "Egna Minnen Beträffande Uppfostran" questionnaire for children. Journal of Psychopathology and Behavioral Assessment, 25, 229-237. https://doi.org/10.1023/A:1025894928131.

Olweus, D. (1997). Bully/victim problems in school: Facts and intervention. European Journal of Psychology of Education, 12, 495-510. https://doi.org/10.1007/BF03172807.

Panetta, S. M., Somers, C. L., Ceresnie, A. R., Hillman, S. B., \& Partridge, R. T. (2014). Maternal and paternal parenting style patterns and adolescent emotional and behavioral outcomes. Marriage \& Family Review, 50, 342-359. https://doi.org/10.1080/01494929.2013.879557.

Park, N. (2004). The role of subjective well-being in positive youth development. The ANNALS of the American Academy of Political and Social Science, 591(1), 25-39. https://doi.org/10.1177/0002716203260078.

Perris, C., \& H. Perris (1978): Status within the family and early life experiences in patients with affective disorders and cycloid psychosis. Psychiatric Clinica, 11, 155-162.

Rees, G., \& Main, G. (2015). Children's views on their lives and well-being in 15 countries: A report on the Children's worlds survey. In 2013-14. Children's: Worlds Project (ISCWeB) http://www.isciweb.org/_Uploads/dbsAttachedFiles/ChildrensWorlds2015FullReport-Final.pdf.

Rees, G., Savahl, S., Lee, B. J., \& Casas, F. (Eds.) (2020). Children's views on their lives and well-being in 35 countries: A report on the Children's Worlds project, 2016-19. Jerusalem, Israel: Children's Worlds Project (ISWeB). https://isciweb.org/wp-content/ uploads/2020/07/Childrens-Worlds-Comparative-Report-2020.pdf.

Savahl, S., Montserrat, C., Casas, F., Adams, S., Tiliouine, H., Benninger, E., \& Jackson, K. (2019). Children's experiences of bullying victimization and the influence on subjective well-being: A multinational comparison. Child Development, 20(2), 1-18. https://doi.org/10.1111/cdev.13135.

Schleicher, A. (2018). PISA 2018 Insight and interpretation. https://oecd.org/pisa/PISA\%2020\%Insights\%20and\%20Interpretation\%20FINAL\%20 PDF.pdf.

Setiadi, B. N. (2006). Indonesia: Traditional family in a changing society. In J. Georgas, J. W. Berry, F. J. R. Van De Vijver, C. Kagitcibasi \& P. Y.H. (Eds.), Families across cultures: A 30- nation psychological study (pp. 370-377). Cambridge University Press.

Stavrinides, P., Tantaros, S., Georgiu, S., \& Tricha, L. (2018). Longitudinal associations between parental rejection and bullying/victimisation. Emotional and Behavioural Difficulties, 23(2), 203-212. https://doi.org/10.1080/13632752.2017.1413526.

Sumargi, A., Sofronoff, K., \& Morawska, A. (2015). Understanding parenting practices and parents' views of parenting programs: A survey among Indonesian parents residing 
in Indonesia and Australia. Journal of Child and Family Studies, 24, 141-160. https://doi.org/10.1007/s10826-013-9821-3.

Swearer, S. M., \& Espelage, D. L. (2004). Introduction: A social-ecological framework of bullying among youth. In D. L. Espelage \& S. M. Swearer (Eds.), Bullying in American schools: A social-ecological perspective on prevention and intervention (pp. 1-12). Lawrence Erlbaum Associates Publishers.

Swearer, S. M., Espelage, D. L., Koenig, B., Berry, B., Collins, A., \& Lembeck, P. (2012). A socio-ecological model for bullying prevention and intervention in early adolescence. In S. R. Jimerson, A. B. Nickerson, M. J. Mayer, \& M. J. Furlong (Eds.), Handbook of school violence and school safety: International research and practice (p. 333355). Routledge/Taylor \& Francis Group.

Temel, M., \& Atalay, A. A. (2020). The relationship between perceived maternal parenting and psychological distress: Mediator role of self-compassion. Current Psychology, 39, 2203-2210. https://doi.org/10.1007/s12144-018-9904-9.

Tiliouine, H. (2015). School bullying victimisation and subjective well-being in Algeria. Child Indicators Research, 8, 133-150. https://doi.org/10.1007/s12187-014-9286-y.

Van de Vijver, F. J. R. (2015). Methodological aspects of cross-cultural research. In M. Gelfand, Y. Hong, and C. Y. Chiu (Eds.), Handbook of advances in culture and psychology, Volume 5, (pp. 101-160). Oxford University Press.

Varela, J.J., Sirlopú, D., Melipillán, R., Espelage, D., Green, J., \& Guzmán, J. (2019). Exploring the influence school climate on the relationship between school violence and adolescent subjective well-being. Child Indicators Research, 12, 2095-2110. https://doi.org/10.1007/s12187-019-09631-9.

Veenstra, R., Lindenberg, S., Oldehinkel, A. J., De Winter, A. F., Verhulst, F. C., \& Ormel, J. (2005). Bullying and victimisation in elementary schools: A comparison of bullies, victims, bully/victims, and uninvolved preadolescents. Developmental Psychology, 41(4), 672-682. https://doi.org/10.1037/0012-1649.41.4.672.

Wu, C. W., Chen, W. W., \& Jen, C. H. (2020). Emotional intelligence and cognitive flexibility in the relationship between parenting and subjective well-being. Journal of Adult Development. https://doi.org/10.1007/s10804-020-09357-x

Young, B. J., Wallace, D. P., Imig, M., Borgerding, L., Brown-Jacobsen, A. M., \& Whiteside, S. P. H. (2013). Parenting behaviors and childhood anxiety: A psychometric investigation of the EMBU-C. Journal of Child and Family Studies, 22, 1138-1146. https://doi.org/10.1007/s10826-012-9677-y.

Zevalkink, J., \& Riksen-Walraven, J. M. (2001). Parenting in Indonesia: Inter- and intracultural differences in mothers' interactions with their young children. International Journal of Behavioral Development, 25, 167-175. https://doi.org/10.1080/01650250042000113. 